\title{
A comparative species listing of myxomycetes from tropical (Philippines) and temperate (United States) forests
}

\author{
dela Cruz TEE ${ }^{1,2^{*}}$, Rea MAD ${ }^{1}$, Tran $\mathrm{HTM}^{3}, \mathrm{Ko} \mathrm{Ko} \mathrm{TW}^{4}$ and Stephenson $\mathrm{SL}^{5}$ \\ ${ }^{1}$ Fungal Biodiversity and Systematics Group, Research Center for the Natural and Applied Sciences, University of \\ Santo Tomas, España 1015 Manila, Philippines \\ ${ }^{2}$ Department of Biological Sciences, University of Santo Tomas, España 1015 Manila, Philippines \\ ${ }^{3}$ Department of Biotechnology, Ho Chi Minh International University, Ho Chi Minh City, Vietnam \\ ${ }^{4}$ Fungal Research Foundation, Yangon 11071 Myanmar \\ ${ }^{5}$ Department of Biological Sciences, University of Arkansas, Fayetteville, Arkansas 72701 USA
}

dela Cruz TEE, Rea MAD, Tran HTM, Ko Ko TW and Stephenson SL 2014 - A comparative species listing of myxomycetes from tropical (Philippines) and temperate (United States) forests. Mycosphere 5(2), 299-311, Doi 10.5943/mycosphere/5/2/4

\begin{abstract}
In terms of their flora and fauna, tropical forests are generally reported to be characterized by higher species diversity than temperate forests. Can this also be true for microorganisms such as myxomycetes? In the present study, three lowland tropical forests in the Philippines and three midlatitude temperate forests in north central Arkansas in the United States were surveyed for myxomycetes with the moist chamber technique as it applies to these organisms. Results indicated that more species of myxomycetes were associated with samples of aerial litter (dead but still attached plant parts), forest floor litter and woody twigs collected in Arkansas than for those collected in the Philippines. A higher value for taxonomic diversity also was noted for the temperate forests. However, 19 species listed herein are new records for the Philippines. In the present study, a comparison of the taxonomic diversity of myxomycetes in relation to the number of moist chamber replications was carried out, and this showed that a difference of as many as eight species could occur between what was recorded from a single culture and a series of three cultures prepared from the same sample. Clearly, many of these species could be missed if only a single culture is prepared for a particular sample.
\end{abstract}

Key words - biodiversity - ecoregions - moist chamber replication - slime molds - species list

\section{Introduction}

Tropical ecoregions of the world are known to support higher numbers of species than temperate ecoregions. For instance, approximately 170,000 of the world's 250,000 known species of vascular plants are present in tropical rainforests (Butler 2011). In addition, far more species of herbivorous insects have been recorded from tropical forests than temperate forests (Novotny et al. 2006). This and other comparable comparisons of species diversity for various groups of organisms have tended to support the concept of increasing numbers of species as one moves from temperate forests to tropical forests (Myers et al. 2000, Fromherz 2012). However, determining whether or not this pattern is true for the biodiversity of myxomycetes was the subject of the study reported herein. 
Myxomycetes have been reported from ecosystems worldwide. For example, in temperate forests, myxomycetes were recorded from leaf litter and woody substrates collected in Russia (Novozhilov et al. 2013) and Germany (Schnittler et al. 2006). Surveys of the myxomycetes associated with woody twigs and litter in the woodlands of western Oregon (Ukkola \& Rikkinen 2000) and forests in Kansas, Oklahoma, Arkansas and Virginia in the United States (Stephenson et al. 2008) recorded a high species diversity of these organisms, with overall dominance represented by members of the orders Stemonitales and Physarales. In addition, there are numerous records of myxomycetes from eastern central West Virginia, southwestern Virginia, and the Great Smoky Mountains National Park in western North Carolina and eastern Tennessee (Stephenson et al. 2001, Rosing 2008, Coelho \& Stephenson 2012). In the tropics, more specifically in the Neotropics, myxomycetes have been recorded from Central Chile, Ecuador, Puerto Rico and Costa Rica (Schnittler \& Stephenson 2000, Schnittler 2001, Schnittler et al. 2004, Lado et al. 2012). In contrast, relatively little has been reported on the Paleotropical forests of Asia and Southeast Asia. For example, in northern Thailand, Tran et al. (2006) reported 62 species in 18 genera, with 37 of these representing new records for the country. In the Philippines, Reynolds (1981) reported a total of 107 species for the entire country. Recently, this number was updated to more than 125 with new studies on Lubang Island in Occidental Mindoro (Macabago et al. 2012) and in Mt. Arayat National Park, Pampanga (Dagamac et al. 2012). However, the number of species documented for the Philippines is still relatively small. To date, more species of myxomycetes have been reported from temperate forests than tropical forests. However, we are not aware of any comparative studies that have examined the same types of microhabitats in the two ecoregions with respect to the species present. The present study was carried out to generate a comparative list of myxomycetes associated with ground litter, aerial litter (dead but still attached plant parts above the ground) and twigs in temperate forests of northwest Arkansas in the United States and lowland tropical forests in the Philippines.

\section{Materials \& Methods}

\section{Study sites}

Three lowland tropical forests in the Philippines and three temperate forests in northwest Arkansas in the United States were selected as study sites. The tropical forest study sites were (1) Bataan National Park [BT] $\left(15^{\circ} 02^{\prime} \mathrm{N}, 121^{\circ} 14^{\prime} \mathrm{E}\right)$ in the province of Bataan, with the area actually sampled situated near the Bagac-Morong road and located within a protected area consisting largely of dipterocarp trees; (2) Mt. Palay-Palay National Park[PL] (14 $\left.12^{\prime} \mathrm{N}, 120^{\circ} 35^{\prime} \mathrm{E}\right)$ in the province of Cavite, a lowland forest dominated by dipterocarp trees; and (3) Subic Bay Natural Forest Reserve [SB] $\left(14^{\circ} 48^{\prime} \mathrm{N}, 120^{\circ} 20^{\prime} \mathrm{E}\right)$, an undisturbed lowland dipterocarp forest in the province of Zambales. All three study sites are on the main island of Luzon in the northern Philippines. The temperate forest study sites are located in northwestern Arkansas in the United States. These were (1) Lost Valley in the Buffalo National River [BR] ( $\left.36^{\circ} 01^{\prime} \mathrm{N}, 93^{\circ} 22^{\prime} \mathrm{W}\right)$ in the northeastern Arkansas, a mixed mesophytic forest; (2) Devil's Den State Park [DD] (35 $46^{\circ} \mathrm{N}, 94^{\circ}$ $14^{\prime} \mathrm{W}$ ) in the Boston Mountains south of the city of Fayetteville, a mixed oak-hickory-maple forest; and (3) Pea Ridge National Military Park [PR] (36 $27^{\prime} \mathrm{N}, 94^{\circ} 01^{\prime} \mathrm{W}$ ), a mixed oak-hickory forest in extreme northwestern Arkansas near the border between Arkansas and Missouri.

\section{Collection, characterization and identification of myxomycetes}

Samples of aerial litter (AL), ground litter (GL), and twigs (TW) were collected randomly within the six study sites. Thirty samples of each type of substrate were placed in small paper bags and returned to the laboratory and air-dried prior to be used to prepare moist chamber cultures as described by Stephenson et al. (1994). To prepare the moist chamber cultures, the substrate material was cut into postage stamp-sized pieces and placed in standard Petri dishes lined with filter paper. Three moist chambers were prepared for each individual sample. Distilled water was 
added to each Petri dish and the samples allowed to soak overnight. Afterwards, the $\mathrm{pH}$ of each culture was recorded and the excess water was poured off. Cultures were maintained under diffuse light at room temperature $\left(22-25^{\circ} \mathrm{C}\right)$ for a period of approximately 12 weeks. All cultures were checked each week for the presence of myxomycete plasmodia and/or fruiting bodies.

Fruiting bodies were identified to species using light microscopy and consideration of such morphological characters as spore ornamentation, spore size, stalk length, and the overall shape of fruiting bodies. Reference was made to both the published literature and web-based identification keys (e.g., Eumycetozoan Project [http://slimemold.uark.edu/]). Valid names were based on the nomenclatural information available online for eumycetozoans (http://nomen.eumycetozoa.com).

Taxonomic diversity $(\mathrm{S} / \mathrm{G})$ was calculated as the ratio of the number of species divided by the number of genera (see equation 1). A low $S / G$ value indicates a higher overall taxonomic diversity than a high value. As such, when assessing the taxonomic diversity of an assemblage of myxomycetes, lower values are observed if when the species present are distributed among a relatively large number of genera than when the species belong to just a few genera (Stephenson et al. 1993).

\section{Equation 1}

\section{Taxonomic Diversity =}

\section{Number of myxomycetes species recorded} Total number of myxomycetes genera

\section{Assessment of taxonomic diversity in relation to moist chamber replications}

In the present study, three different moist chamber cultures (A, B and C) were prepared for each sample of substrate material collected. This allowed us to determine to what extent replication of cultures is a factor in recording the species present at a given locality. As such, the number of collections, species, and genera were noted and compared for each individual culture and the pooled data from all three cultures (i.e., only culture A, only culture B, only culture C, and pooled data for $\mathrm{A}, \mathrm{B}$ and $\mathrm{C}$ ).

\section{Results}

\section{Species list of myxomycetes recorded from tropical and temperate forests}

Myxomycetes recorded from the two different ecoregions are listed below. The list is arranged alphabetically by taxonomic order, genus, and species. The abbreviation 'cf.' in the name of a species means that the collection/record could not be identified with certainty. The name of a particular species along with the total number of collections, country of origin (PH or US), the respective study sites (SB, PL, BT, DD, BR and PR) and substrates (AL, GL and TW) from which it was recorded are provided. New records for the Philippines are indicated in bold. It should be noted that some of the new records are based on rather limited material, usually no more than a few fruiting bodies that may have been imperfectly developed. As such, those records with a 'cf.' are best regarded as tentative. However, in every instance, they represented a distinct taxonomic entity clearly different from anything else in the list given below. The same is true for a number of forms (e.g., Physarum sp. A, Physarum sp. B) that could be identified only to genus level.

\section{ORDER CERATIOMYXALES}

Ceratiomyxa fruticulosa (O.F. Müll.) T. Macbr.

Collections: $10(\mathrm{PH}) \quad$ Sites: SB, PL, BT $\quad$ Substrate: TW

\section{ORDER ECHINOSTELIALES}

Clastoderma debaryanum A. Blytt

Collections: 6 (PH), 15 (US) Sites: SB, BT, PR, BR, DD $\quad$ Substrates: GL, TW 
Echinostelium minutum de Bary

Collections: 4 (PH), 17 (US)

Sites: SB, PL, BT, PR, BR, DD Substrates: GL, TW

\section{ORDER LICEALES}

Cribraria microcarpa (Schrad.) Pers.

Collections: 4 (PH), 7 (US) Sites: SB, PL, BT, BR, DD

Substrates: AL, TW

Cribraria violacea $\mathrm{Rex}$

Collections: 6 (PH), 4 (US) Sites: SB, PL, BT, PR, BR

Substrates: AL, GL, TW

Dictydiaethalium plumbeum (Schumach.) Rostaf.

Collection: 1 (US) Site: DD Substrates: TW

Licea belmontiana Nann.-Bremek.

Collection: 1 (US) Site: DD

Substrates: TW

Licea biforis Morgan

Collection: $1(\mathrm{PH})$

Site: BT

Substrates: GL

Licea floriformis var. aureospora M.T.M. Willemse \& Nann.-Bremek.

Collections: $10(\mathrm{PH})$

Sites: SB, PL, BT

Substrates: AL, TW

Licea kleistobolus G.W. Martin

Collection: 1 (US)

Site: BR

Substrates: TW

Licea operculata (Wingate) G.W. Martin

Collections: 1 (PH), 2 (US) Sites: PL, BR

Substrates: TW

Licea rufocuprea Nann.-Bremek. \& Y. Yamam

Collection: 1 (US) Site: PR

Substrate: GL

\section{ORDER PHYSARALES}

Badhamia affinis Rostaf.

Collections: 4 (PH), 7 (US)

Sites: PL, BT, PR

Substrates: AL, GL, TW

Badhamia dubia Nann.-Bremek.

Collections: 4 (US)

Sites: PR, BR

Substrate: TW

Craterium cf. aureum (Schumach.) Rostaf.

Collection: 1 (PH), 1 (US)

Sites: SB, PR

Substrate: TW

Craterium concinnum Rex

Collection: 1 (US) Site: PR

Substrate: AL

Craterium obovatum Peck

Collections: 7 (US)

Sites: PR, DD

Substrates: AL, GL

Diderma chondrioderma (de Bary \& Rostaf.) G. Lister

Collection: 1 (PH), 9 (US)

Sites: BT, PR, BR, DD

Substrates: AL, TW 
Diderma effusum (Schwein.) Morgan

Collections: 51 (PH), 158 (US) Sites: SB, PL, BT, PR, BR, DD

Substrates: AL, GL, TW

Diderma hemisphaericum (Bull.) Hornem.

Collections: 201 (PH), 57 (US) Sites: SB, PL, BT, PR, BR, DD $\quad$ Substrates: AL, GL, TW

Diderma saundersii (Berk. \& Broome ex Massee) E. Sheld.

Collections: 2 (PH), 8 (US) Sites: SB, PR, BR, DD

Substrates: GL, TW

Diderma cf. subdictyospermum (Rostaf.) G. Lister

Collection: $1(\mathrm{PH}) \quad$ Site: BT

Substrate: GL

Diderma squamulosum Alb. \& Schwein

Collection: 1 (US) Site: BR

Substrate: GL

Didymium anellus Morgan

Collections: 10 (PH)

Sites: SB, PL, BT

Substrates: AL, GL

Didymium cf. annulisporum H.W. Keller \& Schokn.

Collection: $1(\mathrm{PH})$

Site: PL

Substrate: GL

Didymium effusum Link

Collection: $1(\mathrm{PH}) \quad$ Site: BT

Substrate: AL

Didymium clavus (Alb. \& Schwein.) Rabenh.

Collections: 2 (PH), 3 (US) Sites: BT, PR, BR

Substrates: AL, GL, TW

Didymium difforme (Pers.) Gray

Collection: 1 (US)

Site: BR

Substrate: GL

Didymium iridis (Ditmar) Fr.

Collections: 13 (PH), 37 (US)

Sites: SB, PL, BT, PR, BR, DD $\quad$ Substrates: AL, GL, TW

Didymium minus (Lister) Morgan

Collections: 52 (PH), 5 (US)

Sites: SB, PL, BT, PR, BR, DD Substrates: AL, GL, TW

Didymium nigripes (Link) Fr.

Collections: 7 (PH), 80 (US)

Sites: SB, PL, BT, PR, BR, DD

Substrates: AL, GL, TW

Didymium ochroideum G. Lister

Collections: 7 (PH), 4 (US)

Sites: SB, PL, BT, BR

Substrates: AL, GL, TW

Didymium serpula Fr.

Collections: 2 (PH)

Site: SB

Substrate: GL

Didymium squamulosum (Alb. \& Schwein.) Fr. \& Palmquist

Collections: 52 (PH), 1 (US) Sites: SB, PL, BT, BR

Substrates: AL, GL, TW

Didymium sp. A

Collections: 2 (PH), 1 (US)

Sites: PL, BT, BR

Substrate: GL 
Didymium sp. B

Collection: 1 (US)

Site: BR

Substrate: GL

Fuligo cinerea (Schwein.) Morgan

Collections: 2 (PH)

Site: PL

Sites: SB, PL, DD

Collections: 4 (PH), 3 (US)

Physarum cf. auripigmentum G.W. Martin

Collection: $1(\mathrm{PH})$

Site: BT

Sites: PR, DD

Substrates: GL, TW

Collections: 10 (US)

Physarum cinereum (Batsch) Pers.

Collections: 13 (PH), 4 (US)

Sites: SB, PL, BT, PR, BR, DD

Substrates: AL, GL, TW

Physarum compressum Alb. \& Schwein.

Collections: 4 (PH)

Sites: SB, PL, BT

Substrates: AL, GL, TW

Physarum crateriforme Petch

Collections: 21 (PH), 4 (US)

Sites: SB, PL, BT, PR, BR

Substrates: AL, TW

Physarum decipiens M.A. Curtis

Collections: 3 (US)

Sites: PR, BR

Substrates: GL, TW

Physarum didermoides (Pers.) Rostaf.

Collections: 2 (US) Site: BR

Substrates: TW, AL

Physarum cf. digitatum G. Lister \& Farquharson

Collection: 1 (US) Site: PR

Physarum echinosporum Lister

Collections: 3 (PH)

Sites: SB, BT

Substrates: GL, TW

Physarum lakhanpalii Nann.-Bremek. \& Y. Yamam.

Collections: $62(\mathrm{PH}) \quad$ Sites: SB, PL, BT

Physarum lateritium (Berk. \& Ravenel) Morgan

Collection: 1 (US) Site: PR

Physarum melleum (Berk. \& Broome) Massee

Collections: 81 (PH), 11 (US)

Sites: SB, PL, BT, PR, BR, DD

Physarum notabile T. Macbr.

Collection: $1(\mathrm{PH})$

Site: PL

Physarum oblatum T. Macbr.

Collections: 26 (PH), 1 (US)
Sites: SB, PL, BT, PR
Substrate: GL

Substrates: AL, GL, TW

Substrate: TW

Substrates: GL, TW

Substrate: TW

Substrates: AL, GL, TW 
Physarum pusillum (Berk. \& M.A. Curtis) G. Lister

Collections: 65 (PH), 14 (US)

Collections: 18 (PH), 2 (US) Sites: SB, PL, BT, DD

Substrates: TW, AL

Physarum serpula Morgan

Collection: 1 (PH)

Site: PL

Substrate: TW

Physarum cf. umbiliciferum Y. Yamam. \& Nann.-Bremek.

Collection: $1(\mathrm{PH}) \quad$ Site: BT

Substrate: TW

Physarum sp. A

Collection: $1(\mathrm{PH})$

Site: SB

Substrate: TW

Physarum sp. B

Collections: 2 (US)

Site: BR

Substrate: TW

Physarum sp. C

Collection: 1 (US)

Site: PR

Substrate: TW

Physarum sp. D

Collection: 1 (US)

Site: BR

Substrate: TW

Physarum sp. E

Collection: 1 (US)

Site: BR

Substrate: TW

Physarum sp. F

Collection: $1(\mathrm{PH})$

Site: SB

Substrate: AL

Physarum sp. G

Collection: 1 (US)

Site: PR

Substrate: TW

Physarum superbum Hagelst.

Collections: 2 (PH)

Site: BT

Substrate: AL

Physarum vermiculare Schwein.

Collection: $1(\mathrm{PH})$

Site: SB

Substrate: AL

Physarum viride (Bull.) Pers.

Collections: 14 (PH), 14 (US)

Sites: SB, PL, BT, PR, BR, DD

Substrates: GL, TW

Willkommlangea reticulata (Alb. \& Schwein.) Kuntze

Collections: 9 (PH), 12 (US)

Sites: SB, PL, BT, PR, BR, DD

Substrate: TW

\section{ORDER STEMONITALES}

Collaria arcyrionema (Rostaf.) Nann.-Bremek. ex Lado

Collections: 103 (PH), 22 (US) Sites: SB, PL, BT, PR, BR, DD Substrates: AL, GL, TW

Collaria elegans (Racib.) Dhillon \& Nann.-Bremek. ex Ing

Collections: 3 (PH), 1 (US) Sites: PL, DD

Substrates: GL, TW 
Comatricha laxa Rostaf.

Collections: $11(\mathrm{PH}), 13$ (US)

Substrates: AL, GL, TW

Comatricha nigra (Pers. ex J.F. Gmel.) J. Schröt.

Collections: 2 (PH), 6 (US) Sites: SB, BT, PR, BR

Substrates: AL, GL, TW

Comatricha pulchella (C. Bab.) Rostaf.

Collections: 17 (PH), 30 (US) Sites: SB, PL, BT, PR, BR, DD

Substrates: AL, GL, TW

Comatricha tenerrima (M.A. Curtis) G. Lister

Collections: 40 (PH), 8 (US) Sites: SB, PL, BT, PR, BR, DD Substrate: TW

Comatricha sp. A

Collections: 14 (US)

Site: PR

Substrate: AL

Diachea bulbillosa (Berk. \& Broome) Lister

Collections: $15(\mathrm{PH}) \quad$ Sites: SB, BT

Substrates: AL, GL, TW

Diachea leucopodia (Bull.) Rostaf.

Collections: 32 (PH), 12 (US) Sites: SB, PL, BT, PR, DD

Substrates: AL, GL, TW

Diachea splendens Peck

Collection: $1(\mathrm{PH}) \quad$ Site: $\mathrm{SB} \quad$ Substrate: GL

Dianema sp. A

Collection: 1 (US)

Site: PR

Substrate: TW

Enerthenema papillatum (Pers.) Rostaf.

Collection: 1 (US) Site: BR

Substrate: TW

Lamproderma arcyrionema Rostaf.

Collection: $1(\mathrm{PH})$

Site: SB

Substrate: AL

Lamproderma scintillans (Berk. \& Broome) Morgan

Collections: 92 (PH), 40 (US)

Sites: SB, PL, BT, PR, BR, DD Substrates: AL, GL, TW

Stemonitis flavogenita E. Jahn

Collection: $1(\mathrm{PH})$

Site: SB

Substrate: TW

Stemonitis fusca Roth (includes Stemonitis fusca var. nigrescens (Rex) Torrend)

Collections: 86 (PH), 68 (US)

Sites: SB, PL, BT, PR, BR, DD

Substrates: AL, GL, TW

Stemonitis herbatica Peck

Collections: 3 (US)

Sites: PR, DD, BR

Substrate: TW

Stemonitis mussooriensis G.W. Martin, K.S. Thind \& Sohi

Collection: 1 (PH), 1 (US)

Sites: PR, BT

Substrate: TW

Stemonitis sp. A

Collection: $1(\mathrm{PH})$

Site: SB

Substrate: AL 
Stemonitis sp. B

Collection: 1 (US)

Site: BR

Site: PR

Site: SB

Substrate: TW

Stemonitis uvifera T. Macbr

Collection: $1(\mathrm{PH})$

\section{ORDER TRICHIALES}

Arcyria affinis Rostaf.

Collections: 2 (PH)

Arcyria cinerea (Bull.) Pers.

Collections: 232 (PH), 219 (US)

Sites: SB, PL, BT, PR, BR, DD

Substrates: AL, GL, TW

Arcyria denudata (L.) Wettst.

Collections: 4 (PH), 13 (US)

Substrate: AL

Substrate: TW

Sites: PL, SB

Substrate: TW

Substrates: AL, TW
Substrate: TW

Arcyria incarnata (Pers. ex J.F. Gmel.) Pers.

Collection: 1 (US) Site: BR

Arcyria insignis Kalchbr. \& Cooke

Collections: 5 (PH), 2 (US) Sites: SB, BR

Substrates: AL, GL, TW

Arcyria marginoundulata Nann.-Bremek. \& Y. Yamam.

Collections: 1 (PH), 8 (US) Sites: PL, PR, DD

Substrates: GL, TW

Arcyria obvelata (Oeder) Onsberg

Collection: 1 (US)

Site: DD

Substrate: TW

Hemitrichia calyculata (Speg.) M.L. Farr

Collection: 1 (US) Site: BR

Substrate: TW

Hemitrichia minor G. Lister

Collections: 6 (PH), 7 (US)

Sites: PL, BT, BR, PR

Substrates: GL, TW

Hemitrichia pardina (Minakata) Ing

Collections: $2(\mathrm{PH})$

Sites: PL, BT

Substrate: TW

Hemitrichia serpula (Scop.) Rostaf. ex Lister

Collections: $2(\mathrm{PH})$

Sites: SB, PL

Substrates: AL, TW

Metatrichia vesparia (Batsch) Nann.-Bremek. ex G.W. Martin \& Alexop.

Collections: 8 (US) Sites: PR, BR, DD

Substrate: TW

Perichaena chrysosperma (Curr.) Lister

Collections: 53 (PH), 63 (US)

Sites: SB, PL, BT, PR, BR, DD

Substrates: AL, GL, TW

Perichaena corticalis (Batsch) Rostaf.

Collections: 1 (PH), 1 (US) Sites: SB, BR

Substrates: AL, TW 
Perichaena depressa Lib.

Collections: 43 (PH), 5 (US)

Substrates: AL, GL, TW

Perichaena dictyonema Rammeloo

Collections: 2 (PH)

Sites: SB, PL

Substrates: AL, TW

Perichaena microspora Penz. \& Lister

Collections: 2 (PH), 1 (US) Sites: PL, DD

Substrate: GL

Perichaena pedata (Lister \& G. Lister) Lister ex E. Jahn

Collections: 3 (PH), 6 (US) Sites: BT, BR

Substrates: AL, GL

Perichaena vermicularis (Schwein.) Rostaf.

Collections: 4 (PH), 1 (US) Sites: SB, BT, DD

Substrates: AL, TW, GL

Trichia botrytis (J.F. Gmel.) Pers

Collection: 1 (US)

Site: BR

Substrate: GL

Trichia favoginea (Batsch) Pers.

Collections: 19 (US)

Sites: BR, PR, DD

Substrates: AL, GL, TW

Trichia lutescens (Lister) Lister

Collections: 5 (US)

Sites: PR, DD

Substrate: TW

Trichia subfusca Rex

Collection: 1 (US)

Site: PR

Substrate: GL

A total of 1,597 collections, 20 genera, and 80 species were recorded from samples of aerial litter, ground litter and twigs collected from tropical forests of the Philippines (Table 1). Subic Bay had the highest number of species (57), followed by Bataan (54) and Mt. Palay-Palay (49), although the latter (2.7) had the highest value for taxonomic diversity among the three Philippine study sites. A particularly high yield was noted for twigs with 700 collections, 55 species and 19 genera as compared to the two types of litter. Nineteen species are also reported here for the first time for the Philippines. Six species (Licea floriformis var. aureospora, Didymium anellus, D. ochroideum, Physarum crateriforme, P. lakhanpalii, and Comatricha tenerrima) were found in all three study sites. Three species (Diderma chondrioderma, Didymium clavus, and Physarum superbum) were recorded only from Bataan, and four species each were reported only from Mt. Palay-Palay (Arcyria marginoundulata, Fuligo cinerea, Licea operculata, and Perichaena microspora) and from Subic Bay (Diderma saundersii, D. serpula, Physarum vermiculare, and Stemonitis uvifera). Badhamia affinis was recorded from both Bataan and Mt. Palay-Palay, whereas Perichaena dictyonema was recorded from Mt. Palay-Palay and Subic Bay.

Samples from temperate forests in the United States yielded 1,089 collections, 23 genera and 82 species (Table 1). Devil's Den National Park had the lowest number of collection (314), genera (19), and species (40) but was characterized by the highest taxonomic diversity (2.1) as compared to the other study sites. The highest yield was observed for twigs (61 species), followed by ground leaf litter (37) and then aerial leaf litter (22).

When the results obtained from the different numbers of moist chamber cultures prepared from the same sample were compared, an appreciable difference was observed for both the number of collections and the number of species (Table 2). In fact, a three-fold increase in the number of collections was recorded when the yield for three cultures was compared with that of a single culture. In addition, the total number of species recorded from a particular sample was higher for the pooled data from three cultures as compared to a single culture. 
Table 1 Number of collections, genera and species of myxomycetes from tropical and temperate lowland forests

\begin{tabular}{lllllllll}
\hline & PH & \multicolumn{1}{c}{ US } & & & Total \\
\hline Study sites & BT $^{\mathrm{a}}$ & PL & SB & Total & BR & DD & PR & Totections \\
\hline Number of collect & 528 & 535 & 534 & 1,597 & 508 & 314 & 267 & 1089 \\
Number of genera & 18 & 18 & 17 & 20 & 19 & 19 & 21 & 23 \\
Number of species & 54 & 49 & 57 & 80 & 55 & 40 & 51 & 82 \\
\hline S/G Ratio & 3.0 & 2.7 & 3.4 & 4.0 & 2.9 & 2.1 & 2.4 & 3.6 \\
\hline Substrates & AL $^{\mathrm{b}}$ & GL & TW & Total & AL & GL & TW & Total \\
\hline Number of collections & 522 & 375 & 700 & 1,597 & 219 & 362 & 508 & 1089 \\
Number of genera & 14 & 13 & 19 & 20 & 11 & 16 & 22 & 23 \\
Number of species & 47 & 39 & 55 & 80 & 22 & 37 & 61 & 82 \\
\hline S/G Ratio & 3.4 & 3.0 & 2.9 & 4.0 & 2.0 & 2.3 & 2.8 & 3.6 \\
\hline
\end{tabular}

${ }^{\text {a }}$ Study sites:

PH: BT, Bataan Natural Park, Bataan; PL, Mt. Palay-Palay National Park, Cavite; SB, Subic Bay Forest Reserve, Zambales US: BR, Buffalo National River, Arkansas; DD, Devil's Den State Park, Arkansas; PR, Pea Ridge National Military Park, Arkansas

${ }^{\mathrm{b}}$ Substrate types: AL, aerial leaf litter; GL, ground leaf litter; TW, decayed twigs

Table 2 Number of collections, genera and species for different replications of moist chamber cultures

\begin{tabular}{lcccccccc}
\hline Sites & PH & B & US & & U & \\
\hline Plates & A & B & C & A+B+C & A & B & C & A+B+C \\
\hline Number of collections & 562 & 524 & 511 & 1,597 & 372 & 349 & 368 & 1,089 \\
Number of genera & 18 & 19 & 19 & 20 & 21 & 20 & 21 & 23 \\
Number of species & 60 & 58 & 53 & 80 & 56 & 53 & 56 & 82 \\
\hline S/G Ratio & 3.3 & 3.0 & 3.2 & 4.0 & 2.7 & 2.7 & 2.7 & 3.6 \\
\hline
\end{tabular}

\section{Discussion}

It is generally acknowledged that for many groups of organisms, species diversity increases as one nears the equator. In theory, the tropical environment would appear to be unusually favourable for the growth and survival of numerous species. The abundant precipitation, typically moderate to warm temperatures, and the complex nature of the vegetation (which provides a multitude of different microhabitats) seem to be the primary reasons why the flora and fauna are so diverse in tropical rainforests (Lugo 1988). However, the opposite trend is said to be the case for myxomycetes, which appear to follow what might be referred to as a "reverse diversity" pattern for temperate and tropical forests (Stephenson et al. 2004). This may be due to the higher number of researchers studying myxomycetes in temperate regions as compared to the mostly rather recent studies and relatively few researchers in the tropics. Indeed, most of what is known about the species diversity of myxomycetes has been reported from temperate regions rather than the tropics (Stephenson et al. 2000). In the present study, we present a comparative species listing of myxomycetes reported from moist chamber cultures prepared with substrate material collected in tropical and temperate forests. Our findings indeed follow what has been reported previously for myxomycete diversity (i.e., a similar reverse diversity trend for the temperate regions of the world, herein represented by the United States as compared to the tropics, herein represented by the Philippines (Table 1). Several factors probably contribute to such a pattern. For example, the high rainfall in the tropics is believed to hinder the formation of fruiting bodies, and there is less leaf litter deposited on the forest floor in the tropics, and the reduced air currents within a closed canopy forest may hinder spore dispersal (Keller \& Everhart 2010).

However, when comparing areas of the Paleotropics such as the Philippines to comparable areas in the Neotropics (e.g., the country of Costa Rica), a similar level of taxonomic diversity can be noted. Interestingly, for tropical forest in both regions, aerial litter has been reported to support more species than ground litter (Rojas \& Stephenson 2008). It has been suggested that the aerial litter microhabitats is simply more suitable for myxomycetes, in part because it is a better spore trap than ground litter in the tropics (Stephenson et al. 2008, Dagamac et al. 2012). 
In contrast, based on the data obtained in this study, aerial litter from temperate forests in this study had the lowest number of species recorded, albeit with the highest taxonomic diversity, the United States study sites (Table 2). This conforms to the data reported by Ndiritu et al. (2009), in which a higher number of species was recorded from ground litter than aerial litter. Stephenson et al. (2008) noted that most of the forest floor in temperate forests was covered with leaf litter with a generally lower decomposition rate as a result of relatively low humidity. This could explain these patterns. Among the three different types of substrates examined in the present study, twigs had the highest number of species recorded for both PH (55 species) and US (61 species). This is in line with the general observation that twigs from temperate deciduous forests are more productive than other types of forests or woodlands (Stephenson et al. 2008).

There was also a variation in the number of collections and species recorded in different replications of moist chamber cultures. As expected, a three-fold increase in the number of collections was recorded in substrates prepared in triplicate (Table 2). What was more surprising was that a higher number of species were recorded in triplicate moist chambers than as single moist chamber. In fact, 20-27 more species could be left out if only one moist chamber culture was used for each substrate sample collected in the Philippines. In the same manner, 26-29 species would have not been recorded from moist chambers of substrates collected in the United States. Such a large difference would likely result in many rare species of myxomycetes being missed. As such, the present study provides clear evidence that preparing only a single moist chamber culture for each sample of substrate material will not yield all of the species of myxomycetes likely to be associated with a particular microhabitat.

\section{Acknowledgements}

This research study was supported by Fulbright Advanced Research and University Lecturing Award given to TE dela Cruz. The authors thank the Research Center for the Natural and Applied Sciences, University of Santo Tomas for the research grant. We appreciate the comments from David W. Mitchell on some of the more problematic collections.

\section{References}

Butler R. 2011 - Rainforest Wildlife. $1^{\text {st }}$ ed. Rainforests. USA: Mongabay.

Coelho IL, Stephenson SL. 2012 - Myxomycetes associated with pipevine, a temperate liana. Mycosphere 3, 245-249.

Dagamac NHA, Stephenson SL, Dela Cruz TEE. 2012 - Occurrence, distribution and diversity of myxomycetes (plasmodial slime moulds) along two transects in Mt. Arayat National Park, Pampanga, Philippines. Mycology 3, 119-126.

Fromherz NA. 2012 - The Case for a Global Treaty on Soil Conservation, Sustainable Farming, and the Preservation of Agrarian Culture. Ecology Law Quarterly.

Keller HW, Everhart SE. 2010 - Importance of myxomycetes in biological research and teaching. Fungi 3, 13-27.

Lado C, de Basanta DW, Estrada-Torres A, Stephenson SL. 2012 - The biodiversity of myxomycetes in central Chile. Fungal Diversity 59, 3-32.

Lugo AE. 1988 - Diversity of tropical species: Questions that elude answers. International Union of Biological Sciences.

Macabago SAB, dela Cruz TEE, Stephenson SL. 2012 - First records of myxomycetes from Lubang Island, Occidental Mindoro, Philippines. Sydowia 64, 109-118.

Myers N, Mittermeier RA, Mittermeier CG, Da Fonseca GA, Kent J. 2000 - Biodiversity hotspots for conservation priorities. Nature 403, 853-858.

Ndiritu GG, Spiegel FW, Stephenson SL. 2009 - Distribution and ecology of the assemblages of myxomycetes associated with major vegetation types in Big Bend National Park, USA. Fungal Ecology 2, 168-183. 
Novotny V, Drozd P, Miller SE, Kulfan M, Janda M, Basset Y, Weiblen GD. 2006 - Why are there so many species of herbivorous insects in tropical rainforests?. Science 313, 1115-1118.

Novozhilov YK, Schnittler M, Erastova DA, Okun MV, Schepin ON, Heinrich E. 2013 - Diversity of nivicolous myxomycetes of the Teberda State Biosphere Reserve (Northwestern Caucasus, Russia). Fungal Diversity 59, 109-130.

Reynolds DR. 1981 - Southeast Asian myxomycetes II. Philippines. Philippine Journal of Biology, $10,127-150$.

Rojas C, Stephenson SL. 2008 - Myxomycete ecology along an elevation gradient on Cocos Island, Costa Rica. Fungal Diversity 29, 117-127.

Rosing WC. 2008 - Myxomycetes of Long Hunter State Park, Davidson County, Tennessee. Castanea 73, 210-213.

Schnittler M. 2001 - Foliicolous liverworts as a microhabitat for Neotropical myxomycetes. Nova Hedwigia 721-2, 259-270.

Schnittler M, Stephenson SL. 2000 - Myxomycete biodiversity in four different forest types in Costa Rica Mycologia 92, 626-637.

Schnittler M, Unterseher M, Tesmer J. 2006 - Species richness and ecological characterization of myxomycetes and myxomycete-like organisms in the canopy of a temperate deciduous forest. Mycologia 98, 223-232.

Stephenson SL, Kalyanasundaram I, Lakhanpal TN. 1993 - A comparative biogeographical study of myxomycetes in the mid-Appalachians of eastern North America and two regions of India. Journal of Biogeography 20, 645-657.

Stephenson SL, Novozhilov YK, Schnittler M. 2000 - Distribution and ecology of myxomycetes in high-latitude regions of the Northern Hemisphere. Journal of Biogeography 27, 741-754.

Stephenson SL, Schnittler M, Lado C. 2004 - Ecological characterization of a tropical myxomycete assemblage-Maquipucuna Cloud Forest Reserve, Ecuador. Mycologia 96, 488-497.

Stephenson SL, Schnittler M, Mitchell DW, Novozhilov YK. 2001 - Myxomycetes of the Great Smoky Mountains National Park. Mycotaxon 78, 1-15.

Stephenson SL, Stempen H, Hall I. 1994 - Myxomycetes: a handbook of slime molds. Portland, Oregon: Timber press.

Stephenson SL, Urban LA, Rojas C, McDonald MS. 2008 - Myxomycetes associated with woody twigs. Revista Mexicana de Micología 27, 21-28.

Tran HT, Stephenson SL, Hyde KD, Mongkolporn O. 2006 - Distribution and occurrence of myxomycetes in tropical forests of northern Thailand. Fungal Diversity 22, 227-242.

Ukkola T, Rikkinen J. 2000 - Myxomycetes in the forests and woodlands of western Oregon. Mycotaxon 76, 213-245. 